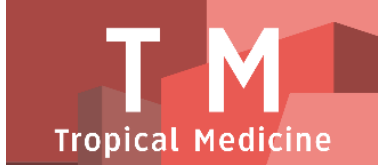

PAPER - OPEN ACCESS

\title{
Uji Aktivitas Antelmintik Ekstrak Etanol Daun Ekor Naga (Rhaphidophora pinnata (L.) Schott) Secara In Vitro
}

\author{
Author \\ DOI \\ : Masfria \\ Electronic ISSN \\ : $10.32734 /$ tm.v1i3.268 \\ Print ISSN \\ : 2623-0542 \\ : 2623-0550
}

Volume 1 Issue 3 - 2018 TALENTA Conference Series: Tropical Medicine (TM)

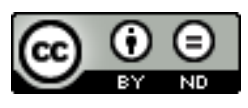

This work is licensed under a Creative Commons Attribution-NoDerivatives 4.0 International License.

Published under licence by TALENTA Publisher, Universitas Sumatera Utara
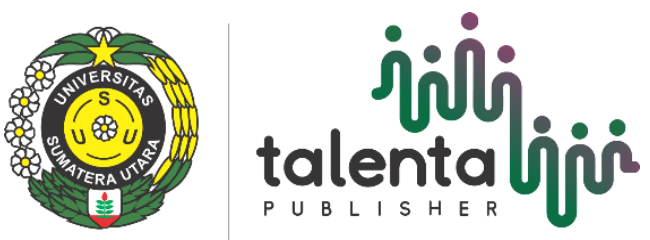


\title{
نَ talentalioi

\section{Uji Aktivitas Antelmintik Ekstrak Etanol Daun Ekor Naga (Rhaphidophora pinnata (L.) Schott) Secara In Vitro}

\author{
Masfria $^{a^{*}}$, Syaiful Amri Lubis ${ }^{b}$, Lenny $^{\mathrm{b}}$ \\ ${ }^{a}$ Fakultas Farmasi, Universitas Sumatera Utara, Medan 20155 \\ ${ }^{b}$ FMIPA, Universitas Muslim Nusantara Alwashliyah, Medan
}

Email*: masfria@usu.ac.id

\begin{abstract}
Abstrak
Kecacingan merupakan permasalahan kesehatan di dunia. Munculnya strain cacing parasit yang resisten terhadap antelmintik menyebabkan pengobatan kecacingan menjadi sulit. Oleh karena itu perlu dilakukan pengujian sumber antelmintik baru. Pengujian ini dilakukan untuk mengetahui skrining simplisia dan ekstrak serta aktivitas antelmintik ekstrak etanol daun ekor naga (Rhaphidophora pinnata $(\mathrm{L}$.)Schoot).Ekstrak didapatkan dengan mengekstraksi serbuk simplisia daun ekor naga (Rhaphidophora pinnata (L.) Schoot) dengan etanol $80 \%$ secara maserasi. Uji aktivitas antelmintik menggunakan cacing Pheretima hupiensis. Pirantel pamoat dengan konsentrasi $20 \mathrm{mg} / \mathrm{mL}$ digunakan sebagai kontrol positif. Aktivitas antelmintik ekstrak etanol daun ekor naga ditentukan berdasarkan waktu paralisis dan lisis Pheretima hupiensis. Hasil pengujian serbuk simplisia dan ekstrak etanol daun ekor naga mengandung senyawa alkaloid, flavonoid, glikosida, saponin, tanin, dan steroid/triterpenoid. Ekstrak etanol daun ekor naga (Rhaphidophora pinnata(L.) Schoot) memiliki aktivitas antelmintik terhadap cacing Pheretima hupiensis pada konsentrasi 30, 20, 15, 10, $5 \mathrm{mg} / \mathrm{mL}$ mampu membunuh cacing dengan waktu berturut-turut adalah 29,22; 46,80; 63,69; 82,66; 131,28 menit. Kelompok kontrol positif (pirantel pamoat) memiliki waktu kematian 107,64 menit sedangkan control negatif memberikan hasil negatif. Analisis statistika waktu kematian cacing dengan uji Tukey menunjukkan perbedaan secara signifikan dengan nilai $\mathrm{p}<0,05$. Ekstrak etanol daun ekor naga (Rhaphidophora pinnata (L.) Schoot) mempunyai daya antelmintik terhadap cacing Pheretima hupiensis. Aktivitas antelmintik meningkat seiring dengan peningkatan konsentrasi ekstrak ethanol daun ekor naga.
\end{abstract}

Kata kunci: Antelmintik, Ekor naga, Rhaphidophorapinnata(L.) Schoot, Pheretimahupiensis.

\begin{abstract}
Worm infection is a health issue in the world. The development of anthelmintic- resistant parasitic worm strains has caused difficulty to treat the infection. Therefore, it is necessary to find sources of new anthelmintics. This study was performed to determine the screening of dried powder and extract, also evaluate the anthelmintic activity of the ethanolic extract of ekor naga's (Rhaphidophora pinnata (L.) Schoot) leaves. The extract was obtained by extracting the dried powder of the ekor naga's leaves with $80 \%$ ethanol by maceration method. The anthelmintic activity of the extract was tested against Pheretima hupiensis worms. Pyrantel pamoate with concentration of $20 \mathrm{mg} / \mathrm{mL}$ was used as positive control. The anthelmintic activity of the extract was determined based on the time of paralysis and lysis of Pheretima hupiensis. The results of the screening showed that the dried powder and the ethanol extract of ekor naga'sleaves contained alkaloid, flavonoids, glycosides, saponins, tannins, and steroids / triterpenoids compounds. The ethanol extract of ekor naga's leaves (Rhaphidophora pinnata (L.) Schoot) showed anthelmintic activity against Pheretima hupiensis at concentrations of 30,20,15, 10, and $5 \mathrm{mg} / \mathrm{mLwith}$ the ability of killing worms at 29.22 , $46.80,63.69,82.66$, and 131.28 minutes, respectively. The positive control group (pyrantelpamoate) showed the killing time at 107.64 minutes, and the negative control gave a negative result. The statistical analysis of the mortality time of worms using Tukey test showed a siginificant difference with $\mathrm{p}$ value $<0.05$. The ethanol extract of ekor naga's leaves (Rhaphidophora pinnata (L.) Schoot) has anthelmintic activity against Pheretima hupiensis worms. The anthelmintic activity increases due to the increase of the ekor naga's leaves extract concentration.
\end{abstract}

Keywords: Anthelmintics, Rhaphidophora pinnata(L.) Schoot, Pheretima hupiensis. 


\section{Pendahuluan}

Penyakit infeksi merupakan salah satu penyakit yang menjadi permasalahan utama di negara-negara berkembang seperti di Indonesia. Salah satu infeksi yang paling umum yaitu infeksi cacing [1]. Infeksi cacing merupakan penyakit yang paling umum dan menjangkit banyak manusia di seluruh dunia. Sampai saat ini penyakit cacing masih tetap merupakan suatu masalah karena kondisi sosial dan ekonomi di beberapa bagian dunia [2]. Di Indonesia, penyakit cacing adalah penyakit rakyat, infeksinya pun dapat terjadi secara simultan oleh beberapa jenis cacing sekaligus. Diperkirakan lebih dari 60\% anak-anak di Indonesia menderita suatu infeksi cacing, rendahnya mutu sanitasi menjadi penyebabnya. Pada anak-anak, cacingan akan berdampak pada gangguan kemampuan untuk belajar, dan pada orang dewasa akan menurunnya produktivitas kerja [2].

Penyakit kecacingan ditularkan melalui makanan dan minuman yang terkontaminasi telur cacing. Penyakit cacing sangat merugikan karena cacing tersebut mengambil zat-zat gizi dalam usus. Gejala klinis yang ditimbulkan diantaranya kekurangan gizi, diare, anemia, kerentanan terhadap penyakit [3]. Selain itu, seseorang yang terkena penyakit cacing akan menunjukkan perut buncit, berat badan menurun, batuk, demam, asma serta mual [4]. Gejalagejala ini terjadi karena cacing hidup dalam rongga usus manusia dan mengambil makanan terutama karbohidrat dan protein. Setiap 20 ekor cacing dewasa akan mengambil karbohidrat 2,8 gram/hari dan protein 0,7 gram/hari [2]. Pengobatan dengan menggunakan tanaman berkhasiat obat merupakan salah satu alternatif yang dipilih untuk memperkecil adanya efek samping karena pemberian obat sintetis. Telah banyak diketahui tanaman yang berkhasiat sebagai tanaman obat, salah satunya tanaman yang berkhasiat obat adalah daun ekor naga (Rhaphidophora pinnata (L.)Schott). Pada umumnya masyarakat mengkonsumsi tanaman ekor naga dengan cara meminum air rebusan daun untuk penyakit batuk, tumor, kanker, anemia, reumatik, benjolan-benjolan daging yang tumbuh pada kulit dan membersihkan darah kotor, [5].

Kandungan kimia yang terdapat dalam daun ekor naga (Rhaphidophora pinnata (L.) Schott) memiliki aktivitas antibakteri terhadap beberapa bakteri [6]. Dari hal tersebut perlu dilakukan pengujian aktivitas antelmintik dari daun ekor naga (Rhaphidophora pinnata (L.) Schott). Menurut beberapa peneliti, kemampuan daya antelmintik ini berkaitan dengan kandungan senyawa tanin, saponin, flavonoid, dan steroid diduga mempunyai aktivitas antelmintik $[1,7,8]$.

Berdasarkan uraian di atas maka perlu dilakukan pemeriksaan skrining golongan senyawa kimia yang terdapat pada simplisia dan ekstrak etanol serta uji aktivitas antelmintik ekstrak etanol 80\% daun ekor naga (Rhaphidophora pinnata (L.) Schott) secara in vitro terhadap cacing Pheretima hupiensis.

\section{Bahan dan Metode}

Alat-alat yang digunakan adalah alat-alat gelas, naraca kasar (Ohaus), neraca listrik (Mattle Toledo), oven (Fisher scientific), blender (Panasonic), mikroskop (Olympus),cawan porselin, desikator, aluminium foil, penangas air, lemari pengering, cawan petri, mat pipet, stopwatch, toples tempat menyimpan cacing, rotary evaporator(Haake D). Bahan-bahan yang digunakan adalah simplisia daun ekor naga (Raphidophora pinnata (L.) Schott), etanol 80\%, iodium, bismut (III), asam nitrat, kalium iodida, alfa naftol, asam sulfat, asam klorida pekat, timbal (ii) asetat, raksa (ii) klorida, kristal natrium hidroksida, kloralhidrat, besi (iii) klorida, isopropanol, metanol, kloroform, n-heksana, tween 80, larutan fisiologi $\mathrm{NaCl}$ 0,9\% dan cacing Pheretima hupiensis.

Skrining golongan senyawa kimia serbuk simplisia dan ekstrak daun ekor naga meliputi: pemeriksaan senyawa alkaloida, tannin, flavonoida, glikosida, saponin, glikosida antrakinon dan triterpenoida/steroida.

\subsection{Pembuatan Ekstrak Etanol Daun Ekor Naga}

Ekstrak etanol daun ekor naga dibuat secara maserasi dengan pelarut etanol $80 \%$. Sebanyak $400 \mathrm{~g}$ serbuk simplisia dimasukkan ke dalam bejana, kemudian dituangkan dengan 75 bagian cairan penyari etanol $80 \%$ sampai serbuk terendam sempurna, lalu ditutup dan dibiarkan selama 5 hari terlindung dari cahaya, sambil diaduk-aduk. Kemudian campuran diserkai dan ampasnya diremaserasi dengan 25 bagian penyari etanol $80 \%$ dan dibiarkan selama 2 hari, lalu dienap tuangkan sehingga diperoleh 100 bagian maserat. Maserat lalu dipekatkan dengan bantuan alat rotary evaporator pada temperatur tidak lebih dari $40^{\circ} \mathrm{C}$ dan diperoleh ekstrak kental [9].

\subsection{Pembuatan Larutan Uji Ekstrak Etanol Daun Ekor Naga}

Ditimbang sebanyak $5 \mathrm{~g}$ ekstrak etanol lalu ditambahkan1\% Tween 80 ke dalam lumpang, digerus, kemudian ditambahkan $\mathrm{NaCl}$ 0,9\% lalu diencerkan hingga $100 \mathrm{~mL}$ dan diperoleh konsentrasi ekstrak $50 \mathrm{mg} / \mathrm{mL}$. Kemudian dibuat pengenceran dengan konsentrasi $(5,10,15,20,30) \mathrm{mg} / \mathrm{mL}$.Pirantel pamoat digunakan sebagai kontrol positif dengan konsentrasi $20 \mathrm{mg} / \mathrm{mL}$. 


\subsection{Uji Aktivitas Antelmintik Ekstrak Etanol 80\% Daun Ekor Naga Terhadap Cacing Pheretima hupiensis Secara In Vitro}

Uji aktivitas antelmintik dibagi menjadi 8 kelompok yang masing-masing diberi cacing Pheretima hupiensis. Perlakuan uji aktivitas antelmintik ekstrak etanol daun ekor naga sebagai berikut

1. Cawan petri disiapkan, masing-masing berisi larutan $\mathrm{NaCl} 0,9 \%$, larutan $1 \%$ Tween 80 , larutan Pirantel pamoat sebagai kontrol positif dengan konsentrasi $20 \mathrm{mg} / \mathrm{mLdan}$ ekstrak etanol daun ekor naga dengan konsentrasi 5 , 10, 15,20 dan $30 \mathrm{mg} / \mathrm{mL}$.

2. Cacing Pheretima hupiensis dimasukkan ke dalam masing-masing cawan petri.

3. Kemudian dilihat apakah cacing paralisis atau lisis, cacing-cacing tersebut diusik dengan batang pengaduk. Jika cacing diam kemudian ditetesi dengan air panas $\pm 50^{\circ} \mathrm{C}$, bila cacing tetap diam, berarti cacing tersebut telah lisis, tetapi jika bergerak berarti cacing tersebut hanya paralisis. Hasil yang diperoleh dicatat, yang termasuk paralisis dan lisis.

\section{Hasil dan Pembahasan}

Hasil skrining simplisia dan ekstrak menunjukkan adanya golongan senyawa alkaloid, flavonoid, saponin, steroida/triterpenoida, tanin, glikosida. Hasil skriningdapat dilihat pada Tabel 1 berikut:

Tabel 1. Kandungan metabolit sekunder simplisia dan ekstrak etanol daun ekor naga.

\begin{tabular}{llrc}
\hline No. & Golongan Senyawa & Simplisia & Ekstrak Etanol \\
\hline $\mathbf{1}$ & Alkaloid & + & + \\
$\mathbf{2}$ & Flavonoid & + & + \\
$\mathbf{3}$ & Saponin & + & + \\
$\mathbf{4}$ & Steroida/Triterpenoida & + & + \\
$\mathbf{5}$ & Tanin & + & + \\
$\mathbf{6}$ & Glikosida & + & + \\
\hline
\end{tabular}

Keterangan : + = mengandung senyawa yang diperiksa

Adanya senyawa metabolit sekunder yang dikandung pada serbuk simplisia dan ekstrak (tanin, saponin, flavonida, alkaloida, glikosida dan steroid/triterpenoida) yang kemungkinan memberikan efek antelmintik.

\subsection{Hasil Uji Aktivitas Antelmintik}

Aktivitas antelmintik ekstrak etanol $80 \%$ daun ekor naga ditentukan berdasarkan waktu paralisis dan waktu lisis. Efek ekstrak etanol 80\% daun ekor naga terhadap waktu paralisis dan kematian (lisis)Pheretima hupiensis dapat dilihat pada Tabel 2.

Tabel 2. Aktivitas antelmintik ekstrak etanol $80 \%$ daun ekor naga

\begin{tabular}{lcc}
\hline & Tabel 2. Aktivitas antelmintik ekstrak etanol 80\% daun ekor naga \\
\hline Sampel & $\begin{array}{c}\text { Waktu Paralisis } \\
\text { (menit) }\end{array}$ & $\begin{array}{c}\text { Waktu Kematian } \\
\text { (Menit) }\end{array}$ \\
\hline Larutan $\mathrm{NaCl} 0,9 \%$ (kontrol negatif) & - & - \\
Tween $801 \%$ dalam $20 \mathrm{~mL} \mathrm{NaCl}$ (kontrol pelarut) & - & - \\
Pirantel Pamoat $20 \mathrm{mg} / \mathrm{mL}$ (kontrol positif) & $89,70 \pm 3,24$ & $107,64 \pm 4,02$ \\
EEDEN $5 \mathrm{mg} / \mathrm{mL}$ & $121,34 \pm 4,84$ & $131,28 \pm 5,37$ \\
EEDEN $10 \mathrm{mg} / \mathrm{mL}$ & $77,76 \pm 1,62$ & $82,66 \pm 1,65$ \\
EEDEN $15 \mathrm{mg} / \mathrm{mL}$ & $59,22 \pm 0,83$ & $63,69 \pm 1,55$ \\
EEDEN $20 \mathrm{mg} / \mathrm{mL}$ & $42,13 \pm 8,08$ & $46,80 \pm 6,64$ \\
EEDEN $30 \mathrm{mg} / \mathrm{mLl}$ & $26,01 \pm 3,54$ & $29,22 \pm 3,40$
\end{tabular}

Keterangan : EEDEN = Ekstrak Etanol Daun Ekor Naga 


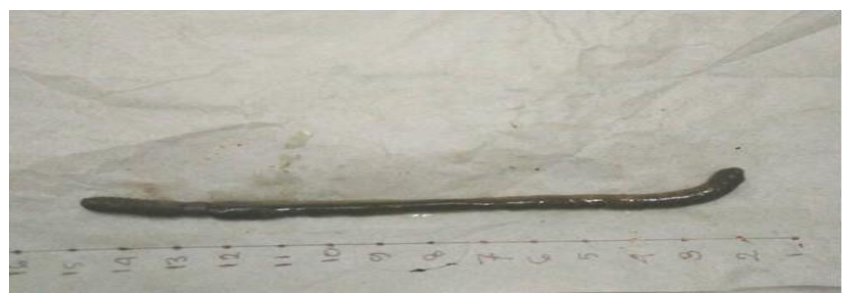

Gambar 1. : Cacing Pheretima hupiensis

Hasil penelitian ini menunjukkan bahwa ekstrak etanol 80\% daun ekor naga memiliki aktivitas antelmintik pada seluruh dosis pengujian. Analisis statistika dengan uji Anova dan Tukey untuk mengetahui konsentrasi mana saja yang memiliki perbedaan yang signifikan secara statistik terhadap waktu paralisis dan waktu kematian cacing Pheretima hupiensis. Hasil uji Tukey dengan taraf signifikan $(\mathrm{p}<0,05)$ menunjukkan bahwa aktivitas ekstrak etanol $80 \%$ daun ekor naga konsentrasi $10 \mathrm{mg} / \mathrm{mL}$ serta pirantel pamoat $20 \mathrm{mg} / \mathrm{mL}$ terhadap waktu paralisis tidak berbeda secara signifikan yaitu $0,052(\mathrm{p}>0,5)$.

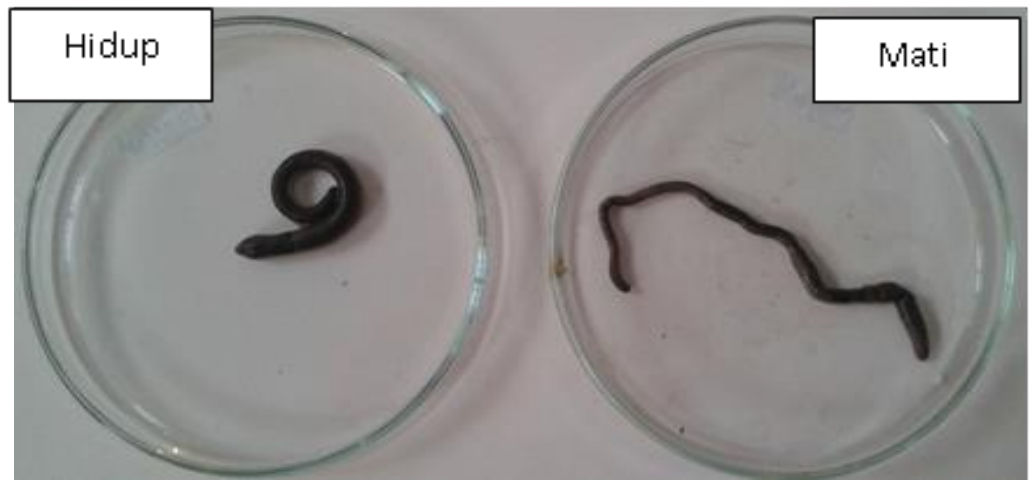

Efek paralisis dipengaruhi oleh dosis dimana semakin tinggi dosis maka waktu paralisis semakin cepat. Kemampuan ekstrak etanol $80 \%$ daun ekor naga pada konsentrasi $30 \mathrm{mg} / \mathrm{mL}$ terhadap paralisis cacing lebih kuat dibandingkan dengan konsentrasi $20,15,10,5 \mathrm{mg} / \mathrm{mL}$ dan pirantel pamoat $20 \mathrm{mg} / \mathrm{mL}$. Analisis statistika waktu kematian cacing dengan uji Tukey menunjukkan bahwa terdapat perbedaan pada setiap kelompok dalam menyebabkan kematian cacing ( $\mathrm{p}<0,05)$. Aktivitas ekstrak etanol 80\% daun ekor naga pada konsentrasi 30, 20, 15 $\mathrm{mg} / \mathrm{ml}, 10,5$ dan pirantel pamoat $20 \mathrm{mg} / \mathrm{mL}$ memiliki perbedaan secara signifikan.

Kemampuan daya antelmintik ekstrak etanol $80 \%$ daun ekor naga diduga disebabkan oleh senyawa metabolit sekunder yang dikandung yaitu tanin, saponin, flavonida, alkaloida, glikosida dan steroid/triterpenoid. Tanin merupakan senyawa polifenol bersifat tidak dapat dicerna oleh lambung dan memiliki efek antinutrisi, berikatan kuat dengan protein dan derivatnya (enzim), karbohidrat dan mineral. Tanin akan mengikat semua unsur tersebut sehingga tidak dapat diserap dan akan dikeluarkan dengan faeses dan memiliki kemampuan untuk menghancurkan mukosa usus [7]. Tanin mengikat protein bebas pada saluran pencernaan cacing atau glikoprotein pada kutikula cacing sehingga mengganggu fisiologis seperti motilitas, penyerapan nutrisi dan reproduksi [10].

Tanin dapat menghambat enzim dan merusak membran. Terhambatnya kerja enzim dapat menyebabkan proses metabolisme pencernaan terganggu sehingga cacing akan kekurangan nutrisi. Membran cacing yang dirusak karena tanin menyebabkan cacing paralisis dan akhirnya akan mati [1]. Saponin merupakan senyawa dalam bentuk glikosida yang tersebar luas pada tumbuhan tingkat tinggi. Saponin membentuk larutan koloidal dalam air dan membentuk busa jika dikocok dan tidak hilang dengan penambahan asam. Saponin dapat berpotensi dalam mematikan cacing karena bekerja dengan cara menghambat enzim asetilkolinesterase sehingga cacing akan mengalami paralisis otot dan berujung pada kematian [8]. Saponin dapat mengiritasi membran mukosa saluran pencernaan cacing sehingga mengganggu penyerapan makanannya. Flavonoid memiliki efek terjadinya vasokontriksi kapiler dan menurunkan permeabilitas pembuluh darah, hal ini mengakibatkan adanya gangguan pembuluh darah sehingga zat-zat makanan dan oksigen yang dibutuhkan cacing terganggu sehingga dapat mempercepat kematian cacing. Cacing bergerak melalui otot longitudinal dan otot sirkular. Kontraksi otot longitudinal menyebabkan tubuh cacing dapat memanjang dan memendek, dan kontraksi otot sirkular menyebabkan tubuh cacing mengembang dan mengkerut. Steroid menyebabkan kerusakan pada otot longitudinal dan otot sirkular sehingga membatasi pergerakan cacing dan cacing 
akan mengalami paralisis. Steroid juga menyebabkan kerusakan membran mukopolisakarida pada lapisan luar cacing sehingga terjadi iritasi dan memicu terjadinya paralisis. Steroid merupakan antioksidan yang mampu menurunkan produksi nitrat sehingga perkembangan cacing tanah terhambat. Steroid mempunyai kerja relaksan yang menyebabkan cacing mengalami paralisis diikuti oleh penurunan permeabilitas yang akhirnya menyebabkan kematian [9].

\section{Kesimpulan}

Hasil skrining senyawa metabolit skunder dari simplisia dan ekstrak etanol $80 \%$ daun ekor naga menunjukkan adanya golongan senyawa metabolit sekunder alkaloida, flavonoida, saponin, steroida/triterpenoida, tanin, glikosida. Ekstrak etanol $80 \%$ daun ekor naga memiliki aktivitas antelmintik terhadap cacing Pheretima hupiensis.

\section{Daftar Pustaka}

[1] Tiwow, D., Bodhi, W., Kojong, N. (2013). Uji Efek Antelmintik Ekstrak Etanol Biji Pinang (Areca catechu) Terhadap Cacing Ascaris lumbricoides Dan Ascaridia galli Secara In Vitro. Manado: Fakultas MIPA. UNSRAT. Penerbit: Pharmacon Jurnal Ilmiah Farmasi. Volume 2. No.2. Hal. 77.

[2] Zulkoni, A. (2011). Parasitologi. Yogyakarta: Penerbit Nuha Medika. Hal. 64, 65, 72.

[3] Winita, R., Mulyati, Astuty, H. (2012).Upaya Pemberantasan Kecacingan Di Sekolah Dasar. Jakarta: Fakultas Kedokteran. Universitas Indonesia. Penerbit: Makalah Kesehatan. Volume 16. No.2. Hal. 65.

[4] Katarina. (2014). Sehat Dengan Herbal Warisan Nenek Moyang: Penumpas Segala Penyakit. Jakarta: Penerbit Media Ilmu Abadi.

[5] Anonima .(2015). http://mediapos.tk/manfaat-khasiat-daun-ekor-naga-untuk-kesehatan/. Diakses 4 Desember 2015/19.00.

[6] Masfria. (2015). Antibacterial activity of Ethyl Acetat and Ethanol extract of Rhaphidopora pinnata (L.f.) Schottleaf against four types of Bacteria, ChemTech; vol.8 No.6, pp.905-914.

[7] Ratnawati et.al. (2013). Aktivitas Anthelmintik Ekstrak Tanaman Putri Malu (Mimosa pudica L.) terhadap Cacing Gelang Babi (Ascaris suum L.). Bengkulu: Fakultas MIPA. Universitas Bengkulu. Penerbit: Prosiding Semirata FMIPA Universitas Lampung. Hal. 90.

[8] Intannia et.al. (2015). Pengaruh Pemberian Ekstrak Etanol dan Ekstrak n-Heksan Daun ketepeng Cina (Cassia alata L.) terhadap Waktu Kematian Cacing Pita Ayam (Raillietina sp.) secara In Vitro. Lampung: Fakultas MIPA. Universitas Lampung Mangkurat. Hal 5 .

[9] Depkes RI. (1989). Materia Medika Indonesia. Jilid IV Cetakan Pertama. Jakarta: direktoratJenderalPengawasanObatdanMakanan. Hal. 516-518.

[10] Asih, A. (2014) Anthelmintik Infusa Daun Andong (Cordyline fructicosa) terhadap Ascaridia galli secara In Vitro. Yogyakarta: Fakultas Teknobiologi. Universitas Atmajaya Yogyakarta.

[11] Novia, A. (2015).Uji In Vitro Antelmintik Ekstrak N-Heksan Daun Pugun Tanoh (Curanga fel-terrae (Lour.) Merr.). Medan: Fakultas Farmasi. Universitas Sumatera Utara. 